\title{
Influence of Fertilizers on Incidence and Severity of Viral and Bacterial Potato (Solanum tuberosum L) Diseases under Field Condition
}

\author{
Ngoh Dooh Jules Patrice ${ }^{1 *}$, Nsimi Mva Armand ${ }^{2}$, Djile Bouba ${ }^{3}$, Boydoul \\ Frederick Ulrich ${ }^{4}$, Philippe Kosma ${ }^{5}$, Ambang Zachee ${ }^{6}$
}

\footnotetext{
${ }^{1,4}$ Department of Biological Sciences, Faculty of Science, University of Maroua, PO Box 814 Maroua, Cameroon

${ }^{2}$ Research Fellow, Institute of Agricultural Research for Development (IRAD) of Dibamba, Cameroon, PO Box, 243

${ }^{3}$ Department of Plants Genetic and Biotechnology, Institute of Agricultural Research for Development of Maroua (IRAD), PO Box 33

${ }^{5}$ Higher National Polytechnic School of Maroua, University of Maroua, PO Box 1450 Maroua

${ }^{6}$ Laboratory of Biotechnologies, Phytopathology and Microbiology Unit, University of Yaounde I, PO Box, 812, Cameroon

*Corresponding author: ndjuliopat@yahoo.fr
}

Received: 2 Oct 2020; Received in revised form: 15 Nov 2020; Accepted: 18 Nov 2020; Available online: 23 Nov 2020

C2020 The Author(s). Published by Infogain Publication. This is an open access article under the CC BY license

(https://creativecommons.org/licenses/by/4.0/).

\begin{abstract}
The potato production in the Far North Region, Cameroon is confronted with rarities or unevenness of rainfall, diseases and pests. In order to improve the production of this plant, a study was conducted in two villages (Mouvou and Gouria) with the general objective of evaluating the impact of fertilizers on the development of viral, bacterial and pest diseases of this plant. The experimental de sign used was a completely randomized block $S$ with 4 treatments repeated 3 timeseach. The fertilizer treatments were: Mycorrhizae (MYC), NPK (20-10-10) chemicalfertilizers, chicken droppings (CD) and a control (T) that received no application. The plant material used was a local variety ofpotato(Dosa). Diseaseswere identified, incidence, severity and rainfall were evaluated. The viral diseases identified were: Virosis M, Rust Stain and PLRV. Bacterial diseases were Bacterial Wiltand Common Scab. The highestincidences of $18.91 \%$ and $10.44 \%$ were obtained with VirosisM and Rust Stain in MYC treatment at Mouvou and Gouria respectively. But, in CD treatment incidence was $2.22 \%$ and $0 \%$ at Gouria for Virosis M and Rust stain respectively. the average rainfall was $697.75 \mathrm{~mm}$. Severity was low in CD treatment in all the sites $(<20 \%)$. All diseases were present in Gouria. The average rainfall was higher in the Gouria site $716.5 \mathrm{~mm}$ than in Mouvou site which received 679 mm of water. The CD treatment can be recommended to the farmers of Mogodéfor the phytosanitary protection of potatoes.
\end{abstract}

Keywords-Solanum tuberosum, fertilizers, diseases, incidence and severity.

\section{INTRODUCTION}

Among agricultural commodities, the potato (Solanum tuberosum L.) occupies a predominant place in the food supply of many countries because of the areas it occupies, the jobs it provides and the production volumes it generates. World production has been estimated at more than 368 million tons from 19.4 million hectares in 2013 (Issa et al., 2017), making it the fourth largest producer after wheat, rice and maize, making it the main non-cereal food in the world (FAO, 2013).

Originally from the highlands of Peru (Spooner et al., 2005), it was introduced to Cameroon in 1940. It is cultivated in high altitude zones (1000 to $3000 \mathrm{~m}$ ) (IRAD, 2012) and extensively in six of Cameroon's ten regions (North-West, South-West, West, Adamaoua, Littoral and Extreme-North), mainly by rural people and mainly women (Fontem et al., 2005). It constitutes a staple food for the populations of these regions 
(annual consumption of 4 to $10 \mathrm{~kg}$ per inhabitant peryear) an important source of income because production surpluses are either sold on the local market or exported to neighboring countries. National production was estimated at 229,000 tons on 23,500 hectares in 2009 (IRAD, 2012). Thus, despite the importance of potatoes in the national economy, total production remains below real potential, yields are generally low (Burton, 1989; Diop et al., 2019) and range between 3 and $11 \mathrm{t} / \mathrm{ha}$, while those of European countries a verage $25 \mathrm{t} / \mathrm{ha}$ ( Sayed et al.2015) and reach $60 \mathrm{t} / \mathrm{ha}$.

In the Far North Cameroon Region, particularly in the Mogodé subdivision (Mayo-Tsanaga), the only and main production area, the low yields observed are associated with poor peasant farming practices (Ngoyi et al., 2020), the scarcity or inequality of the rains and especially to diseases and pests. Many diseases have been reported on potatoes in several countries (Masum et al., 2011; Habtamu et al., 2012 ; Alkher et al., 2015; Son et al., 2018 ) and in Cameroon (Fontem et al., 2003; Fontem et al., 2005 ; Lontsi et al., 2019).

Pota to crop losses due to bacterial diseases could be direct or indirect. Brown rot and Bacterial wilt (Ralstonia solanacearum) of potato are the major bacterial diseases in pota to production a rea (Prior et al. 2016; Kong et al. 2016; Charkowski, 2020). Whereas more than 50 different viruses and one viroid have been reported infecting potatoes worldwide only a handful of them cause major losses globally (Chiunga and Valkonen, 2013). PVY and PLRV (potoato leafroll virus) are now the most damaging viruses of potato world-wide, with PVY having overtaken PLRV as the most important. Tuber yield losses are caused by either of them in single infections and can reach more than $80 \%$ in combination with other viruses. PVX or PVM occurs commonly worldwide and causes losses of $10-40 \%$ in single infections and is particularly damaging in combination with PVY or PVA (Baldo et al., 2010).

Several solutions have been proposed to overcome these diseases production constraints: These include the use of varieties with high production potential, resistant to diseases and adapted to the agro-ecological zone (IRAD, 2012) and the use of chemical fertilizers by farmers. However, these fertilizers when there a re within the reach of farmers, there is la ck of controlover their tis can leads to risks that can disnupt the environmental balance. In the other hand, diseases encountered in the fields are caused by some cultural practices that maintain the development, proliferation or reduction of the pathogens responsible for these diseases, as well as on the parameters that govern the development of epidemics
(Thurston, 1992; Tompkins et al., 1992; Reid et al., 2004). Organic a mendments and composting can affect the inoculum which is the primary source of disease infestation in the field (Thurston, 1992; Compaoreet al., 2010).

On the other hand, the addition of certain mineral and organic fertilizers can lead to the rapid development of plants, making them more or less susceptible to a ttack by pathogens (Thresh, 1982; Na wal et al., 2014; Abiodum et al., 2015). Despite the knowledge about the relationship between fertilizer application and disea ses expression, fertilizer application is adopted by farmers in Cameroon just to increase their crop yield. But, little information is a vailable on the effect of this applied fertilizeron the incidence and severity of diseases of potato. Nevertheless, knowledge of host nutrition in relation to disea se development provides a basis for modif ying cument a gricultural practices to reduce disease incidence and severity.

It is necessary to implement strategies aimed at improving agricultural production that are based on the respect of ecological, economic and toxicological functionalities in the context of food security a nd en vironmental protection. Hence bio fertiliza tion by the use of mycorrhizae, is more resistant to pathogenic bacterial and fungi attacks and exposure to soil toxins (Moser and Haselwandter, 1983; Ngonkeu, 2003; Gna mkoulamba et al., 2018) and orga nic fertilization by the use of chicken droppings that provide more mineral elements (potassium) improves plant resistance to pathogens and environmental balance. Therefore, a study was undertaken with the general objective of evaluating the impact of fertilizers (mycorrhizae and chicken droppings) on the development of potato viral, bacterial diseases in the district of Mogodé(Mayo-Tsanaga) Far-North, Cameroon.

\section{MATERIALS AND METHODS}

\section{Plant material and Fertilizers}

The plant material used for this trial was a local variety of potato (Dosa). Its development cycle is three (3) months. It has a round shape, white skin and flowers.

The mycorrhizal inoculum used for this work consisted of a mixture of spores from fungi of the genera Glomus and Gigaspora. It wa s provided by the Nkolbisson Biotechnology Centre of the University of Yaoundé I.

The organic manure used was chicken droppings from the Teufack Poultry Fa m in Mokolo.

The chemical fertilizer used was NPK (20-10-10) as a maintenance and background fertilizer. 


\section{Experimental design}

The experimental design was in completely randomized blocks. Each block consisted of 4 treatments constituting plot units repeated three times each. The fertilizer treatments consisted of: Mycorrhizae (MYC), chemical fertilizer(NPK); Chicken droppings (CD) and control (T) that received no application. Each site had a total of 60 plants per plot unit. That is 160 plants perblock and 480 plants per site. A total of approximately 960 potato plants were used to set up the trial at the two sites. Each plot was $5 \mathrm{~m}$ long and $5 \mathrm{~m}$ wide. The plots were $1 \mathrm{~m}$ long and $2 \mathrm{~m}$ wide. Each site had an area of $525 \mathrm{~m}^{2}$, $25 \mathrm{~m}$ long and $21 \mathrm{~m}$ wide.

\section{Seeding and fertilizer application}

The sowing was direct seeding with $80 \mathrm{~cm}$ between rows and $25 \mathrm{~cm}$ between bunches at a rate of one pre-germinated tuber per bunch. The depth of sowing was about $2-3 \mathrm{~cm}$.

For mycorrhizae (MYC), the method used was coating. Ten $(10 \mathrm{~g})$ of inoculum was applied with the tubers and per pot at the time of sowing. For the treatment of chicken droppings (CD), $200 \mathrm{~g}$ of were taken and applied per bunch at sowing. Twenty ( $20 \mathrm{~g}$ ) of NPK was applied per bunch 30 days after sowing. The control treatment $(\mathrm{T})$ did not received any application during the entire study.

\section{Evaluation of the effect of treatments on the development of diseases}

Incidence and severity were measured to assess the development of the diseases identified in the treatments. Environmental parameters were quantified by monitoring rainfall at both sites.

\section{Assessment of incidence}

Incidence of diseases were evaluated using the following formula: $I(\%)=\frac{n p}{N} \times \mathbf{1 0 0}$ where, $\mathrm{I}$ is incidence; npnumber of plants showing symptoms per plot; and $\mathrm{N}$ total number of plant in plot

\section{Assessment of severity}

The severity of the disease was assessed by estimating the leaf area occupied by the symptoms of the disease using the formula: Sévérité $=\frac{\sum n \times I}{N} \times \mathbf{1 0 0}$

Where $\Sigma$ is the sum of the products between the number of disea sed plants (a) and the number of plants with the index given in $\%$ (b). $\mathrm{N}$ is the totalnumber of plants in the plot The severity index was used as an estimation scale: $0=$ no symptoms; $1 / 4$ of the diseased leaf corresponds to $25 \%$; $2 / 4=50 \%$ of the attacked leaf; $3 / 4=75 \%$ and $4 / 4=100 \%$ of the disea sed leaves. The number of diseased lea ves per plant was associated with this index.

\section{Quantification of the environment}

The evaluation of rainfall provides information on the degree of precipitation that can influence the state of crop planting and the evolution of the disease. The data were collected using two ra in gauges installed in the middle of the fields in Mouvou and Gouria. Each rain ga uge consisted of a conical tube, hung on a wooden support. Rainfall was measured after each rainfall.

\section{Data Analysis}

Data collected were subjected to analysis of variance (ANOVA) and means were separated using the Duncan's multiple range test (5\%). SPSS 16.0 software was used to perform the statistical analyses.

\section{RESULTS ANDDISCUSSION}

\section{Diseases identified by site}

Table 1: Diseases identified in the Mouvou and Gouria sites (Ngoh Doohet al.2020 in Press)

MOUVOU GOURIA

\begin{tabular}{lll}
\hline Viral diseases & Virose $\mathrm{M}$ & PLRV \\
& Rust stain & Virose $\mathrm{M}$ \\
& Rust stain \\
\hline Bacterialdiseases & Bacterial wilt \\
& Common Scab \\
\hline
\end{tabular}




\section{Impact of fertilizers on the incidence of diseases in the field Incidence of Virosis M}

The analysis carried out revealed a statistically significant difference $(\mathrm{P}=0.02)$ between treatments, with the highest incidences obtained with the MYC treatments, $18.91 \%$ and $16.83 \%$ respectively in Mouvou and Gouria. But, in Gouria incidence was $18.91 \%$. In control, incidence was higher in Mouvou, $15 \%$, than in Gouria, $5 \%$ (Figure 1).

\section{Impact of treatments on the incidence of Rust Stain}

The analysis performed showed that the treatments significantly $(\mathrm{P}=0.013)$ influenced the incidence of the disease in both sites. The highest incidence was obtained in Gouria with the MYC treatment, $10.44 \%$ in contrast to the CD treatment. In contrast, in Mouvou, the highest incidence was obtained with the NPK treatment, $8.88 \%$ while in CD treatment incidencewas low $2.22 \%$ (Figure 1).

\section{Impact of treatments on the incidence of PLRV}

The incidence wa s highest with the NPK treatment $5.55 \%$ than in control $3 \%$. On the contrary, in MYC and NPK treatments the disease was absent in Gouria. (Figure 1). This disea se was absent in Mouvou site.

\section{Impact of treatments on the incidence of bacterial wilt}

The treatments applied significantly influenced $(\mathrm{P}=0.03)$ the average incidence of the disease in Gouria. The highest incidence was obtained with the NPK treatment, $5.55 \%$. In control, incidence was about $2.3 \%$. In MYC and CD treatment in Gourai as well as all treatments in Mouvou, disea se was absent (Figure 1).

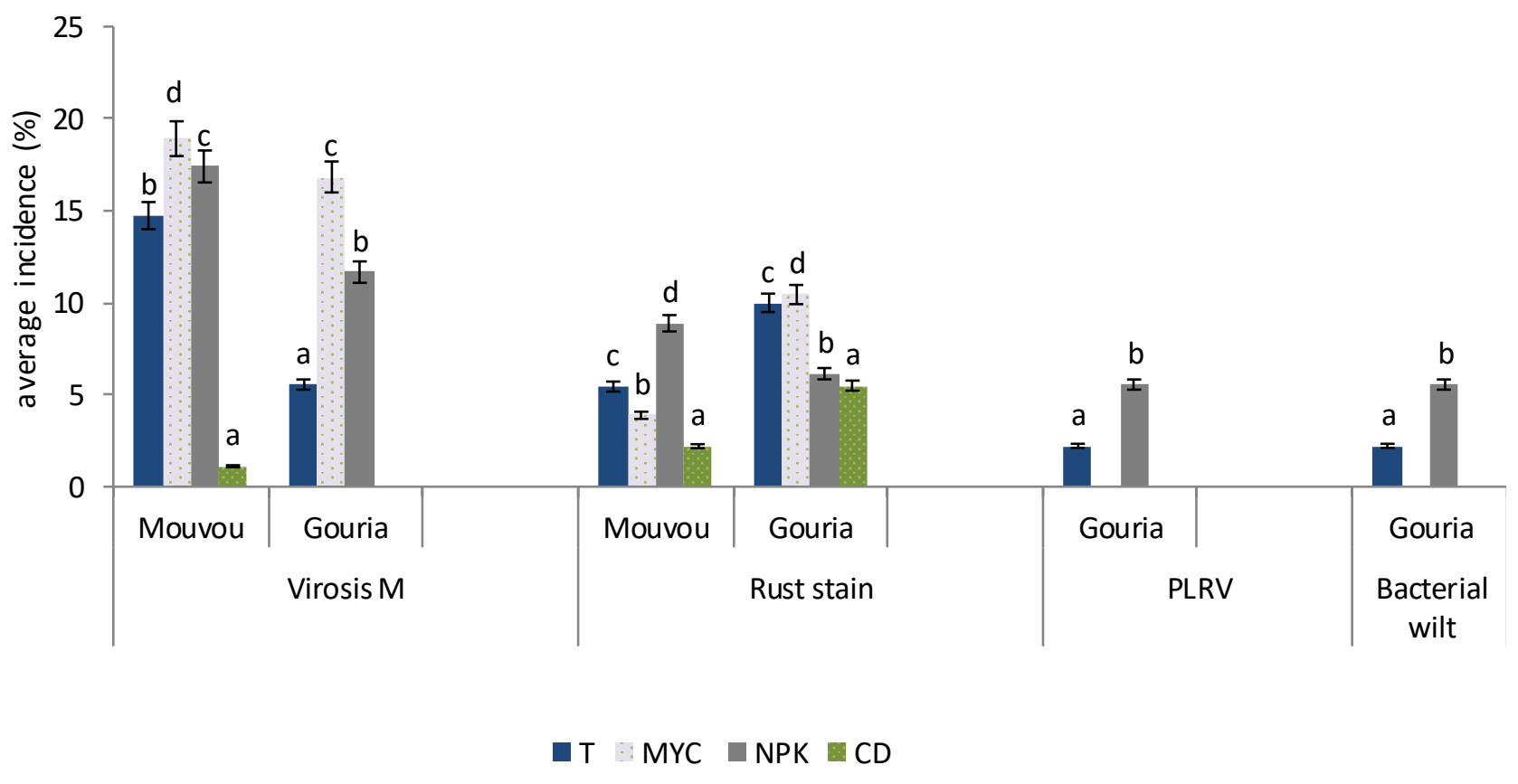

Fig.1: disease incidences at both sites.

$\mathrm{T}=$ control; $\mathrm{MYC}=$ mycorrhizae NPK= chemical fertilizers $; \mathrm{CD}=$ chicken dropping

Values followed by the sa me letter in the same site a re not significantly different at the $5 \%$ threshold according to Duncan's test.

\section{Impact of treatments on severity of diseases in the field}

\section{Impact of treatments on the severity of Virosis M}

The analysis performed showed a statistically significant difference $(\mathrm{P}=0.003)$ between the different treatments applied. This analysis showed that, in Mouvou, the highest sevenity was obtained with the control treatment and NPK, 27.94 \pm 5.08 and $27,45 \pm 5,01 \%$ respectively, while in CD treatment it was
$11.08 \pm 2.14 \%$. In the Gouria site, the MYC treatment obtained the highest severity, $10.97 \pm 3.03 \%$. Disea se wa s absent in CD treatment (Table 2).

\section{Impact of treatments on the severity of Rust Stain}

Statistical analyses show significant difference between treatments $(\mathrm{P}<0.05 \%)$ in the two sites. Highest severities, $21.11 \pm 10.58 \%$ and $20.65 \pm 5.15 \%$ were obtained with the 
control and MYC treatments respectively in Gouria and Mouvou. In CD treatment in Mouvou, severity was low, $9.67 \pm 1.1 \%$ (Table 2 ).

\section{Impact of treatments on the severity of PLRV}

The a naly sis carried out showed that there is no statistically significant difference $(\mathrm{P}=0.70)$ between the different treatments applied to Gouria. It emerged from this analysis that the highest severity was obtained with the NPK treatment, $10.33 \%$ in contrast to the MYC and FP treatment where the disease was absent. The control treatment obtained the average severity of $8 \%$ (Table 2 ).

\section{Effect of treatments on the severity of bacterial wilt}

The treatments applied had a significant influence $(\mathrm{P}=0.03)$ on the severity of the disease in Gouria. This analy sis shows that the highest severities were obtained with the control and NPK treatments, $10.33 \%$ and $8.65 \%$ respectively. The disease was absent in the MYCand CD treatments (Table 2).

Table 2: severity of different diseases in the two sites.

\begin{tabular}{llllll}
\hline \multirow{2}{*}{ Sites } & Diseases & \multicolumn{2}{c}{ Treatments } & & \\
\cline { 3 - 6 } & Virosis M & & TYC & NPK & CD \\
\hline \multirow{2}{*}{ Mouvou } & Rust stain & $27.94 \pm 2.08 \mathrm{c}$ & $24.89 \pm 1.9^{\mathrm{b}}$ & $27.45 \pm 2.01^{\mathrm{c}}$ & $11.08 \pm 2.14^{\mathrm{a}}$ \\
\cline { 3 - 5 } Gouria & Virosis M & $9.83 \pm 1.3^{\mathrm{c}}$ & $20.65 \pm 1.5^{\mathrm{d}}$ & $14.16 \pm 1.01^{\mathrm{a}}$ & $9.67 \pm 2.51^{\mathrm{b}}$ \\
& Rust stain & $8.33 \pm 1.15^{\mathrm{a}}$ & $10.97 \pm 3.73^{\mathrm{b}}$ & $10.71 \pm 2.22^{\mathrm{b}}$ & $*$ \\
& PLRV & $21.11 \pm 2.58^{\mathrm{c}}$ & $12.35 \pm 1.0^{\mathrm{a}}$ & $18.33 \pm 1,9^{\mathrm{b}}$ & $18 \pm 3.1^{\mathrm{b}}$ \\
& Bacterialwilt & $8.0^{\mathrm{a}}$ & $*$ & $10,33^{\mathrm{b}}$ & $*$ \\
\hline
\end{tabular}

$\mathrm{T}=$ control; $\mathrm{MYC}=$ mycorrhizae; $\mathrm{NPK}=$ chemical fertilizers; $\mathrm{CD}=$ chicken droppings.

Values followed by the same letter in the same disease are not significantly different at the $5 \%$ threshold according to Duncan's test.

*Means that the disease wa s absent in the treatment.

\section{Evolution of rainfall in the two study sites}

Rainfall was ra nged from $0 \mathrm{~mm}$ (week 1 of June) to $1620 \mathrm{~mm}$ (week 2 of September) at the Mouvou site with a peak of 1620 $\mathrm{mm}$ observed in the second week of September and from 0 $\mathrm{mm}$ (week 1 of June) to $1800 \mathrm{~mm}$ (week 1 of September) with a peak of $1800 \mathrm{~mm}$ observed in the first week of September at the Gouria site. Average ra infall was higher at the Gouria site $(716.5 \mathrm{~mm})$ than in Mouvou site, which received $(679 \mathrm{~mm})$ (Figure 2).

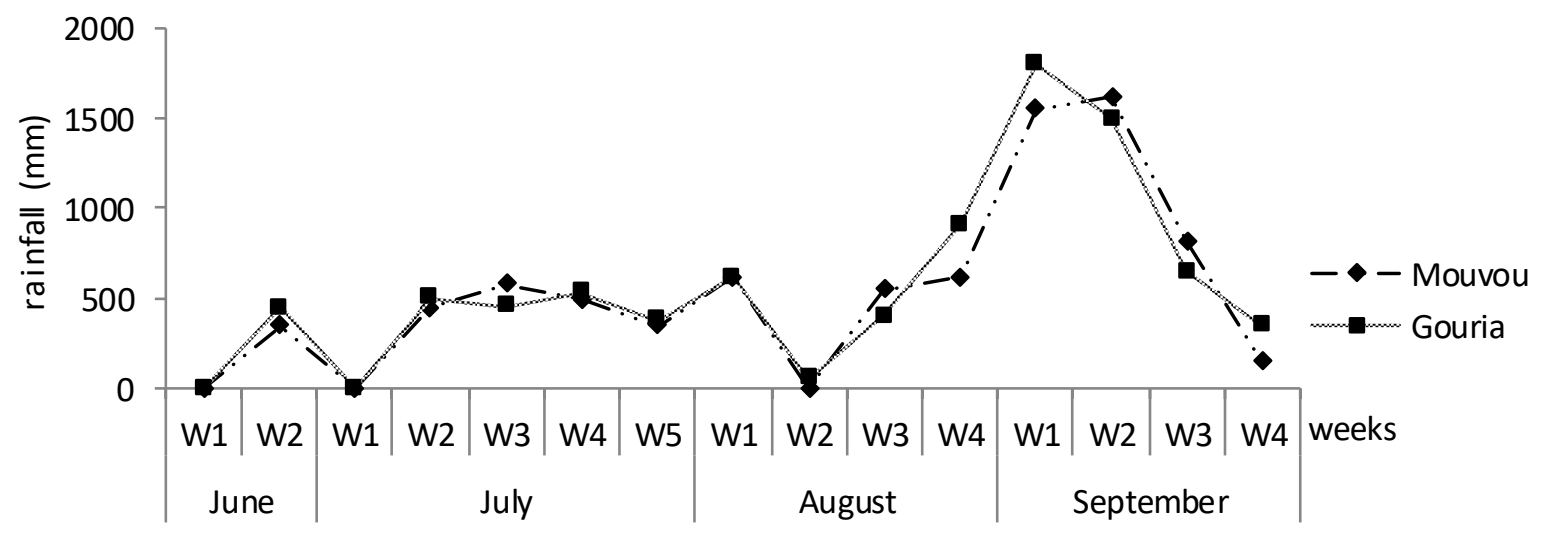

Fig.2: Evolution of rainfall in the two study sites. 
International Journal of Environment, Agriculture and Biotechnology, 5(6)

Nov-Dec, 2020 / Available: https://ijeab.com/

\section{DISCUSSION}

The present work was based on the evaluation of the impact of bio (mycorrhizae), organic (chicken droppings) and chemical (NPK) fertilizers on the development of viral, bacterial and pest diseases of potato crops in the district of Mogodé (Mayo-Tsanaga) Far North, Cameroon. Results obtained in the field showed that potato production is confronted with viral (Virosis M, Rust Stain and PLRV), bacterial (Bacterial Wilt and common scab), ringwom and pest (lepidopteran larvae) diseases. These attacks occurred aftergermination, and mainly during the phases of vegetative growth, flowering, fruiting-maturation and harvesting. These results corroborate those of Mulger and Turkensteen, (2005) and Chiunga and Valkonen (2013). According to these authors, the vegetative propagation mode per tuber favours a greater spread of pathogens than by seed multiplication and it is not rare for a tuber to harbour several pathogens.

Numerous viral diseases and pests such as Virosis M and rust stain were respectively observed during the vegetative growth and flowering phase. This can be explained by the fact that the presence of young leaves, fruiting organs and characteristic odours attract many insects that a re vectors of viral diseases. N'gbesso et al, (2013), ( Lepoivre (2003) and Chiunga and Valkonen (2013) have also showed that the flowers of many plants attract pollinating insects that are considered as vector agents of viral diseases.

The almost homogeneous distribution of viral disea ses under all trea tments in the two sites is explained by the fact that both sites are located in the same a gro-ecological zone (SudanoSa helia nzone), and therefore, there is the presence of similar vector agents (insects) responsible for the transmission of viral diseases disseminated in the zone. This result corroborates that of Traore (1997) who has found that in the sahelian zone, insects are more abundant and therefore responsible for the transmission of many viral diseases. Ngoko, (1994) in his work, highlighted the presence of grey spot (viral disease) in all the agro-ecological zones of Cameroon.

The treatments applied influenced the development of the diseases identified in the two study sites. The incidence and severity of the viral disea ses were low in the CD and MYC treatments in the control. In the $\mathrm{CD}$ treatment, the low rate of $M$ virus and rust stain was explained by the effectiveness of the chicken droppings which provided more mineral elements (e.g. potassium) that improved plant resistance to pathogens and reduced both soil and leaf pathogens. These results are in agreement with those of Hachicha et al. (1992), Compaoré et al. (2010) who have shown that, many minerals like phosphorus and potassium can enhanced resistance of plant in field

On contrary, higher incidence obtained in NPK can be explain by solididy or well being of plant which attracked insects, vectors for pollinisation and viral diseases (Issa et al. 2017). In fact, a potash deficiency will have a direct impact on the maintenance of cell turgidity and thus the regulation of water in the plant. Potash will also be essential for the quality of tuberization. Finally, it will enable the plant to increase its natural resistance, particularly against frost, disea se and drought (Reid et al., 2004). In the other hand, under-oroverfertiliza tion of nitrogen is detrimental to crop productivity. In underdose, it does not allow the plant to have an optimal growth. In over-dose it will fa vour an over-abundant foliage which will be favourable to the development of diseases and will delay maturity and harvest. Nitrogen remains nevertheless essential to ensure good growth (Son et al., 2018).

\section{CONCLUSION}

The incidence and severity of diseases were almost $0 \%$ in the CD trea tment as compared to the control, NPK and MYC treatments. The CD treatment proved to be the most beneficial treatment in terms of potato phytosanitary protection.

\section{REFERENCES}

[1] Abiodun M.O, A., Nafiu K. and. Osunlaja S.O. (2015). Different Rates of Urea as Nitrogen Fertilizer Affect Root and Stalk Rot Diseases of Maize in South West Nigeria. International Journal of Plant \& Soil Science 7(1): 55-66

[2] Alkher H, Islam MR., Wijekoon C, Kalischuk M, Kawchuk LM, Peters RD, Al-Mughrabi K I, Conn KL, Dobinson KF, Waterer D, Daayf F. (2015). Characterization of Phytophthora infestans populations in Canada during 2012. Canadian Journal of Plant Pathology, 37(3): 305-314. DOI : https://doi.org/10.1080/07060661.2015.1053987

[3] Baldo NH, Elhassan SM, Elballa MMA. (2010). Occurrence of Viruses Affecting Potato Crops in Khartoum State-Sudan. Potato Res. 53: 61-67. DOI: https://doi.org/10.1007/s 11540$\underline{010-9150-5}$

[4] Burton W.G. (1989). The Potato. 3rd Ed. Longman Scientific \& Technical, Burnt Mill, 742 p.

[5] Charkowski A, Sharma K, Parker ML, Secor GA, Elphinstone J. (2020). Bacterial Diseases of Potato. In: Campos H., Ortiz 
O. (eds) The Potato Crop. Springer, Cham. pp 351-388. DOI : https://doi.org/10.1007/978-3-030-28683-5 10

[6] Chiunga E and Valkonen JPT. (2013). First report on viruses infecting potato in Tanzania. Plant W.Dis 97:1260. DOI: 10.1094/PDIS-02-13-0143-PDN

[7] Compaore E., Nanema L. S., Bonkoungou S. et Sedogo M. P. (2010). Évaluation de la qualité de composts de déchets urbains solides de la ville de Bobo-Dioulasso, Burkina Faso pour une utilisation efficiente en agriculture.Journal of Applied Biosciences, 33: 2076-2083.

[8] Diop P, Sylla ES, Diatte M, Labou B, Diarra K. (2019). Effect of cut seed tubers and pre-germination on potato tuber yield. Int. J. Biol. Chem. Sci. 13(7): 3157-3163. DOI: https://dx.doi.org/10.4314/ijbcs.v13i7.15

[9] FAO, (2013). Food and Agriculture Organization of the United Nations statistics division. http://faostat3.fao.org/,

[10] Fontem, DA. (2003). Quantitative effects of early and late blights on tomato yields in Cameroon. Tropicultura 21: 36-41

[11] Fonten D.A., Demo, P. \& Njualem, D.K. (2005). Status of potato production, marketing and utilisation in Cameroon. Paper presented at the 9th Triennial Symposium of the InternationalSociety of Tropical Root Crops - Africa Branch,

[12] Gnamkoulamba A. Tounou AK, Tchao M, Tchabi A, Adjevi AKM, Batawila K. (2018). Evaluation au champ du potentiel de croissance et de la production du riz (Oryza Sativa L.) variété IR841 inoculé en pépinière par quatre souches de champignons mycorhiziens à arbuscules. European Scientific Journal $14(12): 452-481$ Doi: :http://dx.doi.org/10.19044/esj.2018.v14n12p452

[13] Habtamu K, Alemayehu C, Bekele K, Pananjay KT. (2012). Evaluation of different potato variety and fungicide combinations for the management of potato late blight (Phytophthora infestans) in Southern Ethiopia. Int. J. of Life Sci., 1(1) : 8-15.

[14] Hachicha R.,HassenA.,Jedidi N. and Kallali H. (1992). Optimal conditions for MSW composting, J Waste Recyc. 33 (6): 76-77.

[15] IRAD, (2012). (Institut de Recherche Agricole pour le Développement), Amélioration durable de la productivité et de la compétitivité de la filière plantain au Cameroun par l'utilisation des technologies innovantes, 4-8p.

[16] Issa M, Ngakou A, Haouvang LC, Nukenine NE. 2017. Potentials of arbuscular mycorrhiza fungi (AMF) and neem (AzadirachtaindicaA. Juss.) leaves extract as biological Control agents against the sweet potato weevil (Cylas puncticollis Boch.) in two Agro-ecological zones of Cameroun. Journal of Experimental Agriculture International, 17 (1): 1-13. DOI : https://doi.org/10.9734/JEAI/2017/35248

[17] Kong HG, Bae JY, Lee HJ, Joo HJ, Jung EJ, Chung E, Lee SW. (2014). Induction of the viable but nonculturable state of Ralstonia solanacearum by low temperature in the soil microcosm and its resuscitation by catalase. PLoS One 9(10):e109792 DOI : https://doi.org/10.1371/journal.pone.0109792

[18] Lepoivre P.(2003). Phytopathologie.De loece, les presses agronomiques de Gembloux,413 P

[19] Lontsi SLD, Ambang Z, Djieto CL, Wouom BCC, Heu A, Pegalepo AN. (2019). Effect of aqueous extracts of Thevetia peruviana $\mathrm{K}$. seeds on the control of late blight and pest insects of Solanum tuberosum L. in Cameroon. Greener Journal of Agricultural Sciences 9 (1): 14-22. DOI Link: http://doi.org/10.15580/GJAS.2019.1.121418176.

[20] Masum MMI, Islam SMM, Islam MS,Kabir MH. (2011). Estimation of loss due to post harvest diseases of potato in markets of different districts in Bangladesh, 2011.African Journal of Biotechnology, 10 (56): 11892-11902. DOI: $\underline{10.5897 / A J B 11.860}$

[21] Moser M. and Haselwandter K., (1983. Ecophysiology of mycorrhizal symbiosis, in: Encyclopedia of Plant Physiology, New Series, vol. 12, Eds O. L. Lange. P. S. Nobel, C. B. Osmond and H. Ziegler. Springer, Berlin-HeidelbergNewYork,) 392-421p.

[22] Mulder A. and Turkensteen, L. J. (2005). Diseases, pests and defects. NIVAP.Editions Potato diseases, $280 \mathrm{p}$.

[23] Nawal I., Abdellatif O. C., Mohamed C., Jihane T., Amina O. T., Rachid B. et Allal D. (2014). Effet de la fertilisation par différents niveaux de N P K sur le développement des maladies foliaires du riz. Journal of Animal \&Plant Sciences. 23 (1): 3601-3625

[24] N'gbesso De Paul MF, N'guessan CK, zohouri GP et konate D. (2013). Evaluation finale du rendement et des paramètres phytosanitaires de lignées de soja [Glycine max (L.) Merrill] dans deux zones agro écologiques de savane de Côte d'Ivoire. Int. J. Biol. Chem. Sci. 7(2): 574-583.

[25] Ngoko Z. (1994). Maize diseases in the highlands of Cameroon. IRA/MINRESI Yaoundé, 22p.

[26] Ngonkeu M.E.L. (2003). Biodiversité et potentiel des champignons mycorhiziens à arbuscules de quelques zones agro écologiques du Cameroun. Thèse de Doctorat $3 \mathrm{e}$, cycle Université de Yaound.é I. 258 p.

[27] Ngoyi AN, Masanga GK, Bila HM, Yashima AY, Milambo MM, Ndjibu LN, Baboy LL. (2020). Effet des amendements organiques sur la croissance et le rendement de la pomme de terre (Solanum tuberosum) cultivée sur un sol dégradé dans la région de Kabinda, République Démocratique du Congo. Int. J. Biol. Chem. Sci. 14(5): 1812-1819, DOI: https://doi.org/10.4314/ijbcs.v14i5.24

[28] Prior P, Ailloud F, Dalsing BL, Remenant B, Sanchez B, Allen C. (2016). Genomic and proteomic evidence supporting the division of the plant pathogen Ralstonia solanacearum into three species. BMC Genomics 17(1):90 DOI : 10.1186/s 12864016-2413-z

[29] Sayed F. El-Sayed \& Hassan A. Hassan \& Mohamed M. ElMogy . (2015). Impact of Bio-and Organic Fertilizers on 
Potato Yield, Quality and Tuber Weight Loss After Harvest. Potato Research 58:67-81DOI 10.1007/s 11540-014-9272-2

[30] Spooner D.M., Mc Lean, K., Ramsay, G.A. (2005). Single domestication for potato based onmiltilocus amplified fragment length polymorphism genotyping. Proc. Natl. Acad. Sci. 102: 14694-14699

[31] Reid LM, Zhu X, Ma BL. (2004). Crop rotation and nitrogen effects on maize susceptibility to Helmenthosporium maydis blight. Plant \& Soil.; 237 (1):1-14.

[32] Son D, Somda I, Legreve A, Schiffers B 2018. Effect of plant diversification on pest abundance and tomato yields in two cropping systems in Burkina Faso: farmer practices and integrated pest management. Int. J. Biol. Chem. Sc. 12 (1) : 101-119. DOI : $10.4314 /$ acsj.v9i1.27638

[33] Stuart W, Platt HW (Bud), Nigel C. (2008). Diseases, Pests and Disorders of Potatoes - A Colour Handbook. Manson Publishing Ltd, London, UK

[34] Thresh J, 1982. Cropping practices and virus spread. Annu.Rev.phytopathol, 20:.193-218.

[35] Thurston, H D. (1992). Sustainable practices for plant diseases management in traditional farming systems New Delhi,Westvew Press\& Oxford \& IBH Publishing Co.Pvt.Ltd..

[36] Tompkins DK, Wright AT, Fowler DB. (1992). Foliar disease development in no-till winter wheat: influence of agronomic practices on powdery mildew development. Canadian Journal of Plant Science, 72:965-972

[37] Traore N.S. (1997). Etude bioécologique des Cicadelles du genre Cicadulina (Homoptera Cicadellidae), vectrices de la striure du maïs au Burkina Faso. Implication épidémiologique. Thèse de doctorat d'Etat, Université de Cocody, Abidjan, Cote d'Ivoire, $248 \mathrm{p}$. 